кандидат юридических наук, старший преподаватель кафедры государственноправовых дисциплин Ростовского филиала Российского государственного университета правосудия

\section{TЕОРЕТИКО-ПРАВОВЫЕ ОСОБЕННОСТИ ОПРЕДЕЛЕНИЯ МЕСТА ЭКОНОМИЧЕСКОГО ПРАВА В СИСТЕМЕ РОССИЙСКОГО ПРАВА}

PhD in Law, Senior Lecturer, State and Legal Subjects Department, Rostov branch of Russian State University of Justice

\section{THE PLACE OF ECONOMIC LAW IN THE SYSTEM OF RUSSIAN LAW: THEORETICAL AND LEGAL ASPECTS}

В cmamье рассматривается место экономиче ского права в системе права, в целях обособления данной группы правоотношений автор использует концепцию микромоделей системы права. Применяются методы анализа системы и структуры права и инфильтрации правовых норм для формирования экономическо-правовой микромодели системы права с последующим генезисом новых отраслей и институтов права. Подчеркиваются значимость экономического права в системе российского права и ее влияние, взаимосвязь и соотношение с другими отраслями права. Автор предполагает, что появление новой отрасли права повлечет за собой пересмотр уже существующих правоотношений в сфере экономической деятельности государства с сопутствующими увеличением диспозитивных норм и уменьшением императивных и создаст предпосылки разработки новых учебных дисциплин и направлений подготовки.

Ключевые слова:

экономическое право, система и структура права, отрасль права, микромодель, экономическая деятельность, генезис отраслей и институтов, синергетический эффект.

Summary:

The study discusses the place of economic law in the system of law. To isolate this group of legal relations, the author uses the concept of micromodels of the legal system. Such methods as the analysis of the system and structure of law and the infiltration of legal rules are applied to create an economic and legal micromodel of the legal system followed by the genesis of new branches and institutions of law. The study emphasizes the importance of economic law in the system of Russian law and highlights its influence, interrelation and correlation with other branches of law. The author assumes that a new branch of law will entail revising the existing legal relations in the field of state economic activity accompanied by an increase in discretionary rules and a decrease in imperative ones and will set the stage for new academic subjects and majors.
\end{abstract}

Keywords: economic law, system and structure of law, branch of law, micromodel, economic activity, genesis of branches and institutions, synergistic effect.

B XX в. борьбу двух идеологий (капитализма и коммунизма) разрешило экономическое развитие, рыночная экономика победила государственное экономическое планирование. Рыночные отношения более адекватно и гибко реагировали на быстро изменяющуюся реальность. Так называемые пятилетки в СССР зачастую к моменту выполнения планов теряли всю актуальность и становились способом отчетности и элементом идеологической пропаганды, а не эффективным экономическим инструментом.

При рассмотрении экономических моделей современных государств можно заметить, что все ведущие экономики мира используют капиталистическую модель, за исключением Китая, где достаточно удачно действует симбиоз различных моделей. Многие страны, не имеющие значительных природных и человеческих ресурсов, но соблюдающие экономические законы, которые исправно работали на протяжении нескольких веков, а некоторые - и тысячелетий, добивались экономических успехов, а иногда и экономического «чуда». Игнорирование этих правил всегда заканчивалось плачевно для государства.

Экономическая теория классифицирует экономические кризисы следующим образом: объективные, связанные с циклическими процессами в экономике, и субъективные, созданные человеком или природой. Если первые (мировой экономический кризис 1929-1939 гг., азиатский фринансовый кризис 1997-1998 гг., мировой экономический кризис 2008 г.), коррелирующие с экономическим циклом, почти неизбежны и требуют минимизации экономических потерь, то причинами вторых (экономических кризисов в Чили 1971-1974 гг., Аргентине конца 1990-х - начала 2000-х гг., валютного кризиса в России 2014-2015 гг., экономических кризисов, длящихся в Венесуэле с 2016 г., Зимбабве - 
с конца 1990-х гг.) являются политические события, природные катастрофы, ошибки в управлении. Правовой инструментарий способен помочь избежать только субъективных кризисов.

На первый взгляд, простой секрет заключается в выполнении экономических законов, что гарантирует развитие и благоденствие, но как отсутствие правового регулирования, так и «зарегулированность» ведут к краху экономики. Поэтому идеальным сочетанием выступает соблюдение экономических законов на базе рационального правового регулирования, построенного на способе предоставления возможностей, а не их ограничения.

Также необходимо учитывать существование рисков в экономико-правовом пространстве. Ю.А. Тихомиров приходит к выводу, что «анализ и предотвращение рисков должны быть важной задачей теории права, теории государства и всех отраслевых наук, особого внимания заслуживают риски в зоне соотношения национального и международного права» [1, с. 35]. Предотвращение рисков должно стать одной из обязательных целей практического применения научных достижений в экономическом праве.

Принимаемые нормативные предписания должны быть нацелены на стимулирование предпринимательской и иной незапрещенной экономической деятельности, на повышение благосостояния российских граждан. Это возможно только в том случае, если между различными формами выражения права будут установлены системные связи [2, с. 14].

Определение места экономического права в системе российского права - не только теоретическая потребность, но и установление места экономических законов и принципов в государственном управлении. В развитом государстве, каким позиционирует себя Россия, политика не может находиться выше экономики. Согласимся с мнением Е.М. Ашмариной, которая считает, что «экономические отношения являются базисными (основными), а право и политика - надстроечными элементами» [3, с. 7]. Если провести аналогию, то экономическое развитие - это стратегическая цель деятельности государства, достигаемая путем реализации тактических задач (правовых, политических и др.).

По нашему мнению, предметом экономического права являются отношения, возникающие в процессах производства, распределения, перераспределения материальных и иных благ для удовлетворения потребностей государства, общества и индивида, которые урегулированы принципами и нормами права. Достаточно широкое определение вызвано повсеместным присутствием экономических отношений в жизни социума и государства. Также следует выделить основные признаки обозначенной группы общественных отношений:

- объединяет нормы других отраслей российского права в сфрере экономической деятельности, таких как конституционное, административное, фринансовое, предпринимательское, международное, трудовое, корпоративное, уголовное право и др.;

- предназначается для регулирования отношений в области экономической деятельности;

- состоит из различных структурных единиц в зависимости от критерия классификации (публичное и частное экономическое право, международное и национальное экономическое право и производные), от направленности (конституционное, административное, финансовое и др.) и видов экономической деятельности в соответствии с общероссийским классификатором (ОКВЭД).

Кроме того, стоит заметить, что такая отрасль отечественного права, как международное публичное право, уже имеет в своем составе группу отношений, посвященных международному экономическому праву. Соответственно, в российской системе права присутствует экономическое право, однако действующее только при реализации «внешних» отношений, для «внутренних» таковое отсутствует, что создает правовой дисбаланс, демонстрирующий управление экономикой внутри страны согласно политической конъюнктуре, а не экономической целесообразности.

Экономическое право уже преподается университетах некоторых ведущих стран (Германии, Франции, Израиля и др.). При этом Россия, установившая в Конституции основные черты системы рыночной экономики, такие как единство экономического пространства, свободу перемещения товаров, услуг и финансовых средств, поддержку конкуренции, свободу экономической деятельности, равную защиту всех фрорм собственности, для успешной интеграции в мировое экономическое сообщество должна осуществлять рецепцию положительного опыта других государств.

Например, 1990 г. в Оксфордском университете, Университете Гента, Университете Париж-Дофин и Университете Эразма Роттердамского начала действовать магистерская программа «Европейский магистр в области права и экономики» (EMLE - European Master in Law and Economics) [4]. На сегодняшний день она реализуется и учебными заведениями - партнерами (университетами Гамбурга (Германия), Болоньи (Италия), Марселя (Франция), Вены (Австрия), Хайфы (Израиль), Варшавской школой экономики (Польша) и Институтом исследований развития им. Индиры Ганди (Индия)). Кроме того, EMLE поддерживает связь с Калифорнийским уни- 
верситетом в Беркли (США). Программа получила признание и финансовую поддержку Европейского союза и была включена в проект «Сократ» (Socrates) под патронажем Европейской комиссии по обмену студентами и сотрудничеству между вузами.

Сегодня и в ведущих высших учебных заведениях России стали открываться магистерские программы по направлению подготовки 40.04.01 «Юриспруденция»: «Международное экономическое (коммерческое) право», «Информационные правоотношения в инновационной экономике», «Правовое обеспечение предпринимательской деятельности "Право и бизнес"» (Московский государственный университет); «Право международной торговли, финансов и экономической интеграции» (Высшая школа экономики); «Экономическое право» (Санкт-Петербургский государственный экономический университет); «Юрист в сфере мировой экономики» (Московский государственный юридический университет); «Экономическое правосудие», «Правовое обеспечение рыночной экономики», «Магистр инновационного и предпринимательского права в бизнеспроектах России» (Российская академия народного хозяйства и государственной службы при Президенте РФ); «Юрист в сорере экономической деятельности» (Российский государственный университет правосудия), что только лишний раз подтверждает повышающийся спрос на квалифицированных специалистов в области экономики и права.

Некоторые авторы (Е.М. Ашмарина, В.В. Ершов, В.Н. Корнев, Е.В. Терехова) представляют экономическое право как микромодель системы права, мы попытались раскрыть понятие микромодели и проанализировать этот феномен.

Такое новое и пока еще спорное явление в праве, как микромодель, представляет собой уменьшенный аналог системы российского права, включающий в себя создание параллельно существующей специализированной системы права с помощью выделения правовых норм в зависимости от критерия обособления, без изменения принадлежности к какой-либо отрасли и (или) институту. Таким образом, мы получаем новую, меньшую по масштабам, но не по значимости, систему права, которая также имеет отрасли и институты, но только касающиеся экономической деятельности. Следствием выступает формирование экономического публичного права и экономического частного права.

Экономическое публичное право будет включать в себя следующие компоненты:

- экономическое конституционное право,

- экономическое муниципальное право,

- экономическое административное право,

- экономическое финансовое право,

- международное публичное экономическое право,

- экономическое уголовное право.

Экономическое частное право будет содержать следующие составляющие:

- предпринимательское право,

- коммерческое право,

- трудовое экономическое право,

- международное частное экономическое право.

По поводу отсутствия в предлагаемой системе норм гражданского права присоединимся к мнению Е.М. Ашмариной, которая считает, что они «реципированы такими отраслями, как предпринимательское и коммерческое право, и составляют базовую часть этих отраслей» [5, с. 145].

Созданная таким образом новая система права будет неразрывно связана с общей системой российского права как часть и целое. При этом трансформации общей системы никак не отразятся на новой, а изменения в последней смогут повлечь модификацию общей, тем самым закрепив и обозначив место экономики в жизнедеятельности государства. Также стоит учитывать синергетический эффрект от объединения экономических составляющих различных элементов структуры права в новой системе. Подобная синергия может иметь индуктивный характер, и за счет коррекции части может измениться целое. Например, взаимодействие конституционного и финансового права в новой системе способно вызвать необходимость перемен в области политических правоотношений в общей системе. Тем самым реализуется постулат «экономика выше политики».

На наш взгляд, нужно учитывать, что после того как экономические отношения будут выделены из системы права и перенесены в микромодели, многие отрасли перестанут соответствовать понятию отрасли права и выделятся в институты. Либо путем объединения схожих по сущности предмета и метода правового регулирования они образуют новую отрасль права, обладающую синергетическим потенциалом и существующую только в экономической микромодели российского права. 
Например, фринансовое право в данной микромодели при взаимодействии с предпринимательским и административным правом может сформировать новую комплексную отрасль, которая будет регулировать участие государства в рыночных отношениях и управление государственными компаниями, корпорациями, предприятиями.

Государственные и муниципальные предприятия, являясь субъектом гражданских правоотношений, могут выступать участниками предпринимательской деятельности, особенность которой состоит в стремлении к получению прибыли. При этом государство, помимо получения доходов, должно не забывать о социальных обязательствах. Рационально используя экономический инструментарий, оно способно осуществлять предпринимательскую деятельность, находя баланс между публичными и частными интересами. Преобладание публичного интереса может выражаться в стремлении государства заработать, несмотря на нанесение экономического урона обществу, что может привести к осознанному нарушению законодательства со стороны социума.

Теория микромоделей, на наш взгляд, является более подходящим способом выделения и последующего объединения норм, институтов, отраслей права в обособленную правовую систему. Однако возникает вполне справедливый вопрос: «Чем микромодель отличается от комплексной отрасли?»

Результат, который мы получили, образовав микромодель системы права, превзойдет эффект от комплексной отрасли. Путем объединения различных отраслей и институтов права мы сорормируем новые структурные правовые взаимосвязи, что может привести к генезису новых элементов системы права. На основании полученных результатов возможна разработка учебных дисциплин, способных функционировать в рамках не только существующих юридических специальностей, но и новых направлений подготовки бакалавров и магистров.

\section{Ссылки:}

1. Тихомиров Ю.А. Риски в правовом пространстве // Юридическая техника. 2019. № 13. С. 28-35

2. Мирошник С.В. Экономическое право в системе российского права // Вопросы экономики и права. 2016. № 1 (91). С. 12-14.

3. Ашмарина Е.М. Экономическое право как микромодель системы российского права // Там же. 2015. № 6 (84). С. 7-13.

4. European Master in Law and Economics [Электронный ресурc]. URL: https://emle.org (дата обращения: 05.08.2019).

5. Ершов В.В., Ашмарина Е.М., Корнев В.Н. Экономическое право Российской Федерации : монография. М., 2017.284 с.

\section{References:}

Ashmarina, EM 2015, 'Economic Law as a Microcosm of the System of Russian Law', Voprosy ekonomiki i prava, no. 6 (84), pp. 7-13, (in Russian).

Ershov, VV, Ashmarina, EM \& Kornev, VN 2017, Economic Law of the Russian Federation: a Monograph, Moscow, 284 p., (in Russian).

Miroshnik, SV 2016, 'Economic Law in the System of Russian Law', Voprosy ekonomiki i prava, no. 1 (91), pp. 12-14, (in Russian). Tikhomirov, YuA 2019, 'Risks in the Legal Space', Yuridicheskaya tekhnika, no. 13, pp. 28-35, (in Russian) 